\title{
CHANGES IN QUALITY OF LIFE AFTER SHORT AND LONG TERM FOLLOW-UP OF ROUX-EN-Y GASTRIC BYPASS FOR MORBID OBESITY
}

\author{
Rafael M. LAURINO NETO ${ }^{1,2}$ and Fernando A. M. HERBELLA ${ }^{1}$
}

\begin{abstract}
Context - It is unclear whether health-related quality of life (HRQL) is sustained in a long-term follow-up of morbidly obese patients who underwent Roux-en-Y gastric bypass (RYGB). Objective - This study aims to analyze the HRQL changes following RYGB in short and long-term follow-up. Methods - We compared the health-related quality of life among three separate patient groups, using the Medical Outcomes Study 36-Item Short-Form Health Survey (SF-36). Group A - 50 preoperative morbidly obese patients; Group B - 50 RYGB patients 1-2 years post-surgery; Group C - 50 RYGB patients more than 7 years post-surgery. Results - The groups were similar for gender, age and body mass index before surgery. We observed that physical functioning, social function, emotional role functioning and mental health scales did not vary between the three groups. The physical role functioning scale was unchanged in the short-term and decreased compared to the preoperative scale in the long-term follow-up. Bodily pain improved after the operation but returned to the initial level after 7 years. The vitality and general health perceptions improved after the operation and maintained these results after 7 years compared with the preoperative perceptions. Conclusions - RYGB improved health-related quality of life in three SF-36 domains (bodily pain, general health perceptions and vitality) in the short-term and two SF-36 domains (general health perceptions and vitality) in the long-term.
\end{abstract}

HEADINGS - Morbid obesity. Gastric bypass. Weight loss. Quality of life.

\section{INTRODUCTION}

Roux-en-Y gastric bypass (RYGB) is an effective surgical therapy for weight loss and comorbidity remission in morbidly obese patients, although there are still questions regarding short and long-term outcomes and the effect of the operation on health-related quality of life (HRQL) and psychosocial functions ${ }^{(11)}$.

HRQL is a particularly relevant construct in obesity and weight-loss research because obesity has been shown to negatively affect HRQL, which appears to improve with adequate weight loss ${ }^{(16,17)}$.

This study aims to analyze the HRQL changes following RYGB in short and long-term follow-ups.

\section{METHODS}

\section{Study Design}

A controlled cross-sectional design was used. At the same time, a preoperative control group of clinically morbidly obese patients awaiting surgery was compared with two separate groups of patients at two different postsurgical time points: (1) 1-2 years and (2) more than 7 years.

\section{Population}

Three groups (50 patients each) were compared: (1) Group A - preoperative morbidly obese patients; (2) Group B - RYGB patients with 1-2 years post-surgery follow-up (mean 17 months); (3) Group C - RYGB patients with more than 7 years post-surgery follow-up (mean 112 months) (Table 1).

The preoperative group (Group A) consisted of individuals who were accepted into the program and were scheduled and awaiting surgery. The postoperative groups (Groups B and C) consisted of patients who underwent RYGB at Mandaqui Hospital (São Paulo, Brazil).

Group B subjects were part of a 76 patient group (66\% follow-up) with 1-2 years post-surgery follow-up and Group C patients of a 208 patient group (24\% follow-up) with more than 7 years post-surgery follow-up.

The groups were similar for gender $(\mathrm{A} \times \mathrm{B} P=$ 0.2 , A × C $P=0.4$, B × C $P=0.2)$, age $(P=1)$ and body mass index (BMI) $(P=0.4)$ at the time of the operation.

BMI was different in each of the three groups at the last follow-up (A x B $P<0.001$, A x C $P<0.001$, B x C

Declared conflict of interest of all authors: none

${ }^{1}$ Departamento de Cirurgia, Escola Paulista de Medicina, Universidade Federal de São Paulo; ${ }^{2}$ Departamento de Cirurgia, Hospital do Mandaqui, São Paulo, SP, Brasil.

Correspondence: Dr. Rafael Melillo Laurino Neto. Rua Dona Adma Jafet 50 cj 125 - 01308-050 - São Paulo, SP, Brasil. E-mail: rmelillo@uol.com.br 
TABLE 1. Group characteristics before (preoperative) and after (postoperative) surgery

\begin{tabular}{llccc}
\hline & & A & B & C \\
\hline \multirow{3}{*}{ Preoperative } & Age (years) & $42 \pm 11.4(16-62)$ & $42 \pm 10.3(27-63)$ & $42 \pm 10.8(25-61)$ \\
& Gender $(\%$ female) & 80 & 82 & 88 \\
& BMI $\left(\mathrm{kg} / \mathrm{m}^{2}\right)$ & $52 \pm 8.0(41-75)$ & $50 \pm 7.7(40-79)$ & $51 \pm 6.3(38-77)$ \\
\hline \multirow{2}{*}{ Postoperative } & BMI $\left(\mathrm{kg} / \mathrm{m}^{2}\right)$ & & $30 \pm 5.5(22-49)$ & $29 \pm 4.6(21-40)-\mathrm{Nadir}$ \\
& & & $36 \pm 6.3(24-49)-$ Final \\
\hline
\end{tabular}

Group A: preoperative period; Group B: short-term follow-up; Group C: long-term follow-up; BMI: body mass index; Nadir BMI: reached between 1-2 years; Final BMI: reached at last follow-up

$P<0.001)$. Group C showed a significant BMI decrease in the nadir weight, reached $1-2$ years post-surgery $(P<0.001)$ and weight regain at the long-term follow-up $(P<0.001)$ (Table 1$)$.

\section{Surgical Procedure}

All of the patients underwent multidisciplinary evaluations at Mandaqui Hospital (São Paulo, Brazil), including history and physical examination by a surgeon, nutritional evaluation by a registered dietitian and psychological evaluation by a clinical psychologist.

Candidates approved for surgery had a BMI $>40 \mathrm{~kg} / \mathrm{m}^{2}$, or a $\mathrm{BMI}>35 \mathrm{~kg} / \mathrm{m}^{2}$ with significant obesity-associated medical conditions, and had minimal medical, dietary, or psychological contraindications for surgery ${ }^{(14)}$.

All of the individuals who underwent surgery received an open-banded RYGB by the same surgical team using standardized methods ${ }^{(2,13)}$. The surgical technique involved the creation of a $30 \mathrm{~mL}$ gastric pouch, a $100 \mathrm{~cm}$ alimentary limb and a $50 \mathrm{~cm}$ biliopancreatic limb.

Informed consent was obtained from all patients. The protocol was approved by the local ethics committee.

\section{Quality of Life Measure}

The Medical Outcomes Study 36-Item Short-Form Health Survey (SF-36) was used to measure the HRQL. It is a validated and reliable generic HRQL instrument that contains 36-items distributed in eight subscales ${ }^{(6,25)}$. The subscales included physical functioning, physical role functioning, bodily pain, general health, vitality, social functioning, emotional role functioning and mental health. These subscales are described in more detail in Table 2. Each of these functional areas was scored separately, with a score of 100 represented optimal functioning.

All of the questionnaires were self-administered.

\section{Statistics}

The data are expressed as the mean \pm standard deviation [range] for the parametric variables (age, BMI) or the median and interquartile range for the non-parametric variables (scores). A paired $t$-test, the Mann-Whitney U-test, the chi-squared test and an analysis of variance (ANOVA) were used as indicated, and $P<0.05$ was considered significant.

\section{RESULTS}

\section{Quality of Life}

Table 3 shows the HRQL scores for the three groups. The physical functioning, social functioning, emotional role functioning and mental health scales did not vary among the 3 groups $(P=1)$. The physical role functioning scale was similar in non-operated patients (Group A) compared to short term follow-up patients (Group B), although it decreased in a long-term follow-up (A x B $P=0.2, A \times C P<0.001$, $\mathrm{B}$ x C $P<0.001)$. Bodily pain score is lower in Group B compared to Groups A and C (A x B $P<0.001$, A x C $P=0.09$, $\mathrm{B} \times \mathrm{C} P<0.001)$. Vitality is higher short after the operation (Group B) but lower in the long-term follow-up (Group C), although it is still higher than in the preoperative period $(\mathrm{A} x$ B $P<0.001$, A x C $P<0.001$, B x C $P=0.03)$. General health perceptions is better in operated patients $(\mathrm{A} \times \mathrm{B} P=0.02$, A x C $P=0.04, \mathrm{~B}$ × C $P=0.1$ ) (Figure 1).

TABLE 2. Medical Outcomes Study 36-Item Short-Form Health Survey (SF-36) subscales

\begin{tabular}{ll}
\hline Subscale & Description \\
\hline Physical functioning & $\begin{array}{l}10 \text { items which measure limitations in performance of various physical activities, ranging from vigorous activities } \\
\text { to simple self-care functions }\end{array}$ \\
Role physical & 4 items which measure functionality in work and others daily activities as a result of physical health \\
Bodily pain & 2 items which measure degree of pain and pain-related functional limitations \\
General health & 5 items which measure an individual's appraisal of their overall health \\
Vitality & 4 items which measure energy level \\
Social functioning & 2 items which measure health-related limitations in social functioning \\
Role emotional & 3 items which measure functionality in work and others daily activities as a result of emotional health \\
Mental health & 5 items which measure the presence and degree of depression and anxiety \\
\hline
\end{tabular}


TABLE 3. Medical Outcomes Study 36-Item Short-Form Health Survey (SF-36) domains scores for the 3 groups (preoperative, short and long-term follow-up)

\begin{tabular}{|c|c|c|c|c|}
\hline & A & B & $\mathrm{C}$ & $P$ value \\
\hline Physical functioning & $37(0-75)$ & $100(75-100)$ & $75(6-100)$ & 1 \\
\hline Role physical & 77 (50-88)\# & $95(86-100)^{*}$ & $50(25-68) \# *$ & $<0.001$ \\
\hline Bodily pain & $41(31-74) \&$ & $84(61-100) \& *$ & $51(22-70)^{*}$ & $<0.001$ \\
\hline General health & $54(40-75) \& \#$ & $92(87-100) \&$ & 72 (58-84)\# & $<0.001$ \\
\hline Vitality & $40(30-70) \& \#$ & $85(75-90) \&$ & $55(40-75) \#$ & $<0.001$ \\
\hline Social function & $56(37-84)$ & $100(87-100)$ & $68(40-87)$ & 1 \\
\hline Role emotional & $33(0-100)$ & $100(100-100)$ & $66(33-100)$ & 1 \\
\hline Mental health & $58(33-75)$ & $90(80-92)$ & $66(48-83)$ & 1 \\
\hline
\end{tabular}

Group A: preoperative period; Group B: short-term follow-up; Group C: long-term follow-up

Data are presented as median (interquartile range $25-75$ ). Like symbols ( $\&$, \#, *) differ $P<0.05$.

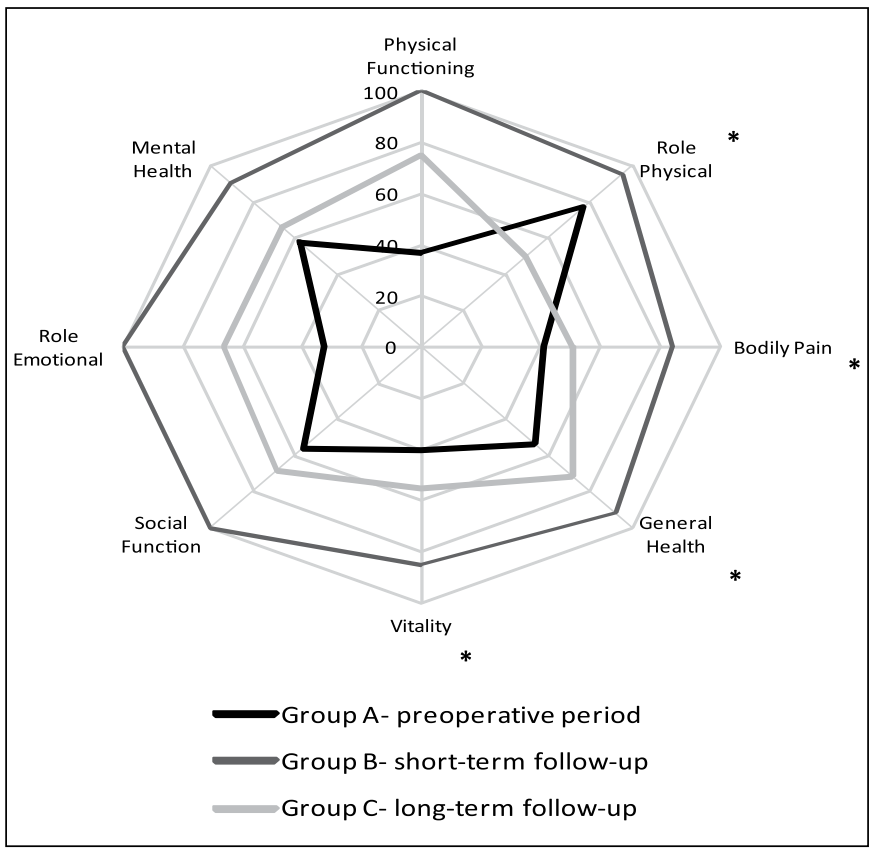

FIGURE1: Polar graph of Medical Outcomes Study 36-Item Short-Form Health Survey. (SF-36) scores at pre operative period (A); short (B); and long term follow-up (C). $* P<0.05$

\section{DISCUSSION}

Morbid obesity is a worldwide public health problem with an estimated 1.7 billion people suffering from the disease worldwide $^{(8,20)}$. This condition is associated with an increased risk of morbidity and mortality from numerous related medical conditions, such as diabetes, coronary artery disease, and several types of cancer; morbid obesity is also related to debilitating psychosocial consequences ${ }^{(11)}$. Poor HRQL has been repeatedly documented in obese patients ${ }^{(21)}$, and HRQL impairment relates to increasing $\mathrm{BMI}^{(12)}$.

Unfortunately, morbidly obese patients respond poorly to traditional dietary and exercise weight-loss regimens, and when an initial response occurs, it is likely to be poorly maintained $^{(23)}$. Surgical interventions were developed as an alternative treatment method for morbid obesity, and are aimed at individuals whose weight-loss attempts have repeatedly failed and whose obesity-related medical and psychosocial problems are overwhelming ${ }^{(10)}$. Bariatric operations are considered an effective therapy for morbid obesity ${ }^{(4)}$ with acceptable complications rates ${ }^{(1)}$, sustained long-term outcomes and increased life expectancy ${ }^{(5,22)}$. Several studies using SF-36 questionnaire have shown an improvement of HRQL after bariatric surgery. Dymek et al. ${ }^{(11)}$ showed significant improvement in three of the eight SF-36 sub-scales (general health, vitality, mental health) immediately after surgery, although most individuals reported some surgery-related pain and functional limitations. There was a significant improvement in an additional three sub-scales 6 months post-surgery (physical functioning, physical role functioning and social functioning). Similarly, Choban et al. ${ }^{(3)}$ examined 53 patients on average 1.47 months (during the rapid weight loss phase) and 23.2 months post-surgery, when the patients had reached a weight plateau. The authors reported continuous improvement of impairments in all areas compared with the preoperative values. At the plateau, the scores were comparable to or even better (emotional role functioning, social functioning, bodily pain, vitality) than the national norm values. Hörchner et al. ${ }^{(15)}$, unlike other authors, did not confirm these HRQL improvements after surgically induced weight loss. They found differences in only $3 \mathrm{SF}-36$ domains (bodily pain, general health and mental health) before and after 1 and 2 years of surgical interventions. These studies results are controversial and limited to 2 years of follow-up, which corresponds to the period of better surgical outcomes in terms of weight loss.

Some recent studies have reported weight regain in a long-term follow-up of operations in $50 \%$ of patients, with therapeutic failure ( $<50 \%$ of excess body weight lost) between 7 and $20 \%$ after 8 postoperative years ${ }^{(19,24)}$. However, only few studies have addressed HRQL in a long-term follow-up when weight regain is manifest. Interestingly, HRQL seems to be improved even in a long-term follow-up. Dixon et al. ${ }^{(9)}$ examined 459 patients before surgery and annually up to 4 years after Lap-Band placement. All of the SF-36 mean scores improved significantly compared with the community norms at the 1-year assessment and remained so for 4 years. Similarly, de Zwaan et al. ${ }^{(7)}$ compared a preoperative group 
(78 patients) with a postoperative group (110 patients) of RYGB patients with an average follow-up time of 13.8 years and found significant differences in favor of the postoperative group in all SF-36 sub-scales except for mental health.

In the present study, we showed that three (social function, emotional role functioning and mental health) of four mental health related domains of SF-36 survey did not change, because these domains, as previously observed, are probably less impaired by obesity ${ }^{(7,9)}$. Among the physical health related domains, only physical functioning, which measures the limitations in physical activity performance, did not change. This fact might be attributed to the irreversible effects of some comorbidities, such as cardiovascular disease and arthropathy ${ }^{(9,18)}$. In a different manner, physical role functioning which measures functionality in work and others daily activities as a result of physical health, did not improve in the short-term. Physical role functioning was also lower in the long-term follow-up compared to the initial measurements; we believe this result is linked to aging and the decreased motivation related to aging since the groups had similar ages at the time of operation, but the last measurements of group $\mathrm{C}$ was performed 7 years later ${ }^{(9)}$. Bodily pain showed initial improvement but returned to the pre surgical situation in the long-term follow-up, which may reflect short-term euphoria and the belief that a long-term disability has been relieved what was not confirmed in the long-term follow-up ${ }^{(3)}$. Finally, general health perceptions and vitality, which are related to individual perceptions of overall health and energy levels, improved in the short-term and maintained the improvements in the long-term follow-up, representing the best surgical results.

Our study has some limitations. First, a significant number of patients were lost of follow-up (34\% for Group B and $76 \%$ for Group C). Even though a team of Social Workers tried unsuccessfully to contact lost patients, the continental size of Brazil, the pattern of referral, and the characteristics of this population (low income, high mobility) was likely responsible to the high number of patients lost of follow-up. The fate of the weight loss and comorbidities status in these patients is unknown since patients with good outcomes may choose not to continue follow-up as much as patients with worse results may seek another institution. Another limitation is the cross-sectional design of the study. However, all groups were equated on presurgical variables (gender, age and BMI), which suggest that the differences between the groups were indeed because of the different surgical time frames, rather than error or cohort effects.

\section{CONCLUSIONS}

Our results showed that RYGB improved HRQL in three SF-36 domains (bodily pain, general health perceptions and vitality) in the short-term and two domains (general health perceptions and vitality) in the long-term follow-up. HRQL showed worse outcomes in the long-term follow-up, which may be related to the following issues: (1) weight regain; (2) the irreversible effects of comorbidities; (3) the recurrence of comorbidities; (4) aging; and (5) decreased motivation.

Laurino Neto RM, Herbella FAM. Alterações da qualidade de vida no seguimento a curto e longo prazos de indivíduos obesos mórbidos submetidos à derivação gástrica com Y de Roux. Arq Gastroenterol. 2013,50(3):186-90.

RESUMO - Contexto - Ainda não está claro se as melhorias na qualidade de vida relacionada a saúde se sustentam no acompanhamento a longo prazo de pacientes obesos mórbidos que se submetem a derivação gástrica com Y de Roux (RYGB). Objetivo - Este estudo tem como objetivo analisar as alterações na qualidade de vida relacionada a saúde no acompanhamento a curto e longo prazos de obesos mórbidos submetidos a RYGB. Métodos Foram comparados aspectos da qualidade de vida relacionada a saúde entre os três grupos distintos de pacientes, usando o questionário 36-Item Health Survey Short-Form (SF-36). Grupo A - 50 pacientes obesos mórbidos no pré-operatório, Grupo B - 50 pacientes submetidos à RYGB 1-2 anos pós-cirurgia e, Grupo C - 50 pacientes submetidos à RYGB há mais de 7 anos. Resultados - Os grupos comparados eram semelhantes quanto ao sexo, idade e índice de massa corporal antes da cirurgia. Quanto aos aspectos componentes do questionário SF-36, observou-se que capacidade funcional, aspectos social e emocional e saúde mental não variaram quando se comparou os resultados dos três grupos. Quanto ao componente aspectos físicos, observou-se que permaneceu inalterado na avaliação de curto prazo e piorou em comparação aos valores obtidos no pré-operatório no seguimento a longo prazo. O componente dor corporal melhorou após a operação, mas voltou para nível semelhante ao pré-operatório após 7 anos. Vitalidade e estado geral de saúde melhoraram após a operação e apresentaram manutenção destes resultados após 7 anos, em comparação com as percepções pré-operatórias. Conclusões - RYGB melhorou a qualidade de vida relacionada a saúde em três domínios do SF-36 (dor, estado geral de saúde e vitalidade) no seguimento a curto prazo e dois domínios SF-36 (estado geral de saúde e vitalidade) a longo prazo.

DESCRITORES - Obesidade mórbida. Derivação gástrica. Perda de peso. Qualidade de vida. 


\section{REFERENCES}

1. Buchwald H, Estok R, Fahrbach K, Banel D, Sledge I. Trends in mortality in bariatric surgery: a systematic review and meta-analysis. Surgery. 2007;142:621-35.

2. Capella RF, Capella JF, Mandec H, Nath P. Vertical banded gastroplasty-gastric bypass: preliminary report. Obes Surg. 1991;1:389-95.

3. Choban PS, Onyejekwe J, Burge JC, Flancbaum L. A health status assessment of the impact of weight loss following Roux-en-Y gastric bypass for clinically severe obesity. J Am Coll Surg. 1999;188:491-7.

4. Choban PS, Jackson B, Poplawski S, Bistolarides P. Bariatric surgery for morbid obesity: why, who, when, how, where, and then what? Cleve Clin J Med. 2002;69:897-903.

5. Christou NV, Sampalis JS, Liberman M, Look D, Auger S, McLean AP, MacLean LD. Surgery decreases long-term mortality, morbidity, and health care use in morbidly obese patients. Ann Surg. 2004;240:416-23.

6. Ciconelli RM, Ferraz MB, Santos W, Meinão I, Quaresma MR. [Brazilian-Portuguese version of the SF-36. A reliable and valid quality of life outcome measure]. Rev Bras Reumatol. 1999;39:143-50.

7. de Zwaan M, Lancaster KL, Mitchell JE, Howell LM, Monson N, Roerig JL, Crosby RD. Health-related quality of life in morbidly obese patients: effect of gastric bypass surgery. Obes Surg. 2002;12:773-80.

8. Dietel M. Overweight and obesity worldwide now estimated to involve 1.7 billion people. Obes Surg. 2003;13:329-30.

9. Dixon JB, Dixon ME, O'Brien PE. Quality of life after lap-band placement: influence of time, weight loss, and comorbidities. Obes Res. 2001;9:713-21.

10. Dymek MP, le Grange D, Neven K, Alverdy J. Quality of life and psychosocial adjustment in patients after Roux-en-Y gastric bypass: a brief report. Obes Surg. 2001;11:32-9.

11. Dymek MP, Le Grange D, Neven K, Alverdy J. Quality of life after gastric bypass surgery: a cross-sectional study. Obes Res. 2002;10:1135-42.

12. Fabricatore NA, Wadden TA, Sarwer DB, Faith MS. Health-related quality of life and symptons of depression in extremely obese persons seeking bariatric surgery. Obes Surg. 2005; 15:304-9.

13. Fobi MA, Lee H. The surgical technique of the Fobi-Pouch operation for obesity (the transected silastic vertical gastric bypass). Obes Surg. 1998;8:283-8.

14. Gastrointestinal surgery for severe obesity: National Institutes of Health Consensus Development Conference Statement.. Am J Clin Nutr. 1992;55:615S-9S.
15. Hörchner R, Tuinebreijer MW, Kelder PH. Quality-of-life of morbidly obese patients who have undergone a Lap-Band operation: 2 year follow-up study. Is the MOS SF-36 a useful instrument to measure quality of life in morbidly obese patients? Obes Surg. 2001;11:212-8.

16. Karlsson J, Sjöström L, Sullivan M. Swedish obese subjects (SOS) - an intervention study of obesity. Two-year follow-up of health-related quality of life (HRQL) and eating behavior after gastric surgery for severe obesity. Int J Obes Relat Metab Disord. 1998;22:113-26.

17. Kolotkin RL, Crosby RD, Williams GR, Hartley GG, Nicol S. The relationship between health-related quality of life and weight loss. Obes Res. 2001;9:564-71

18. Laurino Neto RM, Herbella FA, Tauil RM, Silva FS, de Lima SE Jr. Comorbidities remission after Roux-en-Y Gastric Bypass for morbid obesity is sustained in a long-term follow-up and correlates with weight regain. Obes Surg. 2012;22:1580-5.

19. Magro DO, Geloneze B, Delfini R, Pareja BC, Callejas F, Pareja JC. Longterm weight regain after gastric bypass: a 5 -year prospective study. Obes Surg. 2008;18:648-51.

20. Ogden CL, Carroll MD, Curtin LR, McDowell MA, Tabak CJ, Flegal KM. Prevalence of overweight and obesity in the United States, 1999-2004. JAMA. 2006;295:1549-55

21. Schok M, Geenen R, van Antwerpen T, de Wit P, Brand N, van Ramshorst B Quality of life after laparoscopic adjustable gastric banding for severe obesity: postoperative and retrospective preoperative evaluations. Obes Surg. 2000;10:502-8.

22. Sjöström L, Narbro K, Sjöström CD, Karason K, Larsson B, Wedel H, Lystig T, Sullivan M, Bouchard C, Carlsson B, Bengtsson C, Dahlgren S, Gummesson A, Jacobson P, Karlsson J, Lindroos AK, Lönroth H, Näslund I, Olbers T, Stenlöf K, Torgerson J, Agren G, Carlsson LM; Swedish Obese Subjects Study. Effects of bariatric surgery on mortality in Swedish subjects. N Engl J Med. 2007;357:741-52.

23. Stunkard AJ, Stinnett JL, Smoller JW. Psychological and social aspects of the surgical treatment obesity. Am J Psychiatry. 1986;143:417-29.

24. Valezi AC, Mali Junior J, de Menezes MA, de Brito EM, de Souza SA. Weight loss outcome after silastic ring Roux-en-Y gastric bypass: 8 years of follow-up. Obes Surg. 2010;20:1491-5.

25. Ware JE Jr, Sherbourne CD. The MOS 36-item short-form health survey (SF-36) I. Conceptual framework and item selection. Med Care. 1992; 30:473-83.

Received 13/2/2013. Accepted 7/5/2013. 